\title{
PENGEMBANGAN INSTRUMEN SIKAP SPIRITUAL PADA SISWA SEKOLAH DASAR
}

\author{
Muhammad Ichsan Muchtar \\ Universitas Negeri Jakarta, DKI \\ Jakarta
}

\section{Kadir}

Universitas Islam Negeri Syarif

Hidayatullah Jakarta

\begin{abstract}
The purpose of this research is to develop spiritual behavior instrument for elementary students. This research used SEM method with second order confirmatory factor analysis with 300 students as the respondents. This study is held in two stageswith 150 respondents in each of them to validate empirical construct and the fitness of the model in overall.The result showed that there were 3 dimensions and 12 indicators with loading factor of $\lambda \geq 0.30$, $t$-calculation $\geq t$-table, and the model meets almost all of goodness of fit index criteria as the requirements to conclude that the model is fit with $C R=0.846>$ 0.7 and $V E=0.599>0.5$. Therefore, the instrument of spiritual attitude for elementary students is deemed valid and reliable.
\end{abstract}

\author{
Keywords \\ Spiritual Attitude, SEM, Second Order Confirmatory Factor Analysis.
}

\begin{abstract}
ABSTRAK
Tujuan penelitian ini adalah untuk mengembangkan instrumen sikap spiritual pada siswa Sekolah Dasar (SD). Penelitian ini menggunakan metode SEM dengan second order confirmatory factor analyisis kepada 300 orang siswa SD dalam dua tahap, masing-masing terdiri dari 150 orang responden, untuk validasi konstruk secara empiris dan ketepatan model (model fit). Hasil analisis uji empiris menunjukkan ada 3 dimensi dan 12 indikator dengan loading factor $\lambda \geq 0.30$, t-hitung $\geq$ t-tabel, model memenuhi hampir keseluruhan kriteria nilai cut off Goodness of Fit Index yang dipersyaratkan untuk model fit, sehingga dikatakan model fit dengan nilai Construct Reliability (CR) dan Variance Extracted (VE) di atas nilai cut-off, yaitu: CR $=0.846>$ 0.7 dan VE $=0.599>0.5$. Dengan demikian, instrumen Sikap Spiritual pada siswa SD sudah valid dan reliabel.
\end{abstract}

Kata Kunci

Sikap Spiritual, SEM, Second Order Confirmatory Factor Analysis

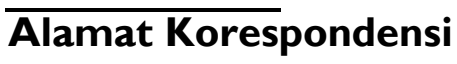 \\ e-mail: \\ m_ichsan_muchtar@yahoo.com
}

krisis cara pandang hidup yang mengalami pergeseran nilai, krisis beban institusi pendidikan yang terlalu besar dengan tuntutan memikul tanggung jawab moral sosial kultural, dan krisis relevansi program pendidikan yang mendukung kepentingan elitis non populis, tidak demokratis, tidak berorientasi ke arah kepentingan mempertahankan prestasi eksistensi kemanusiaan dalam kehidupan bermasyarakat namun beralih kepada orientasi prestise keijazahan.

Konsep sikap spiritual menggambarkan atribut mental seseorang, yaitu: kepribadiannya terhadap objek tertentu, dalam hal ini adalah nilai-nilai spiritual. Reaksi perasaan mendukung atau tidak mendukung merupakan tendensi psikologis yang diekspresikan dengan mengevaluasi entitas konsep spiritual (Alice H. Eagly dan Shelly Chaiken, 1993) yang telah dipelajari untuk direspon secara konsisten bersifat dinamis dan berubah drastis dalam sikap menilai baik buruk, 
terbuka terhadap perubahan disebabkan interaksi seseorang dengan lingkungan sekitarnya (Saifuddin Azwar, 1998) dalam bentuk kesiapan reaksi secara afektif, kognitif, dan konatif (Martin Fishbein, and Ajzen, 1975) terhadap nilai-nilai spiritual berkaitan dengan hubungan manusia dengan Tuhan, manusia dengan dirinya sendiri, dan manusia dengan sesama manusia serta lingkungan.

Berdasarkan uraian latar belakang di atas, fokus penelitian pengembangan instrumen sikap spiritual adalah siswa Sekolah Dasar yang ratarata berusia antara 7-12. Fowler, sebagaimana dikutip oleh Triantoro, mengajukan teori bahwa pada rata-rata usia tersebut memiliki perkembangan spiritual yang disebut kepercayaan mistis-harfiah (misthic-literal faith). Pada tahap ini anak sudah mulai mampu melihat kategori sebabakibat, ruang, dan waktu. Pada tahap ini anak belajar tentang konsep-konsep dimensi spiritual dari orang-orang yang memiliki otoritas di lingkungannya. Sehingga cerita-cerita/dongengdongeng menjadi sarana utama anak untuk mengumpulkan berbagai arti dan makna spiritual. Melalui cerita-cerita yang konkret anak mulai memahami bahwa ada dunia yang bersifat transendental, selain dunia yang dikenalnya. Pada tahap inilah bentuk-bentuk pemahaman dan pencerahan spiritual diperoleh anak, yang selanjutnya makin berkembang dengan mapan jika anak memperoleh masukan yang positif dari lingkungannya (Safaria, 2007). Elkind, sebagaimana dikutip oleh Bridges dan Moore, menjelaskan bahwa siswa Sekolah Dasar berada pada tahap kedua dari tiga tahap perkembangan religiusitas pada masa kanak-kanak dan remaja. Pada tahap ini, anak-anak mengalami peningkatan pemahaman keagamaan berdasarkan perilaku yang diamati (observable behavior) dari pada berdasarkan pemikiran, perasaan, dan motivasi (Bridges and Moore: 2002). Hawari menjelaskan bahwa tumbuh kembang anak seutuhnya dipengaruhi oleh empat faktor yang saling berinteraksi satu dengan lainnya, yaitu: faktor organobiologik, psiko-edukatif, sosial budaya, dan spiritual (agama). Anak akan tumbuh kembang sehat apabila keempat faktor tadi terpenuhi dengan baik. Hal ini sesuai dengan pengertian "sehat" oleh Organisasi Kesehatan se-Dunia (WHO) pada tahun 1984 yang menyebutkan bahwa yang disebut "sehat" itu adalah sehat dalam arti fisik, psikologik, sosial, dan spiritual (Hawari, 1999).

Berdasarkan uraian di atas, masalah yang dirumuskan dalam penelitian ini adalah sebagai berikut:

a. Dimensi dan indikator apa sajakah yang mendasari konsep sikap spiritual pada siswa Sekolah Dasar?

b. Bagaimanakah validitas instrumen sikap spiritual pada siswa Sekolah Dasar?

c. Bagaimanakah reliabilitas instrumen sikap spiritual pada siswa Sekolah Dasar?

\section{Metode Penelitian}

Penelitian ini menggunakan metode Research and Development (R \& D) dengan 4D Model yang dikembangkan oleh Thiagarajan meliputi tahapan: (I) Define (pendefinisian), mulai dari analisis dan sintesis variabel sikap dan spiritual secara teoritis untuk merumuskan konstruk, dimensi, dan indikator variabel untuk selanjutnya disusun definisi konseptual dan definisi operasional variabel sikap spiritual, (2) design (perancangan), mulai dari penyusunan kisi-kisi dan butir-butir instrumen hingga menjadi draft instrumen, (3) develop (pengembangan) dilakukan dengan uji coba draft instrumen kepada 300 orang siswa Sekolah Dasar yang dibagi dalam dua tahap dengan masing-masing responden terdiri dari 150 orang, untuk divalidasi secara konstruk menggunakan Structural Equation Modelling (SEM) sehingga diperoleh butir-butir yang valid secara konseptual, dan (4) diseminate (penyebaran) berupa validasi empirik dengan mengujicobakan butir-butir yang valid secara konseptual menggunakan kriteria internal dan diakhiri dengan perakitan butir-butir instrumen yang valid untuk dijadikan instrumen final (Thiagarajan, 1974).

Teknik pengambilan sampel dilakukan secara acak dengan responden siswa dari SD Islam Al Hikmah dan SD Islam Dwi Matra di Jakarta Selatan. Penelitian ini dilakukan terhadap sampel yakni sebagian dari populasi yang dijadikan sasaran penelitian. Jumlah responden yang menjadi sampel dalam penelitian ini 300 responden.

Pengembangan instrumen sikap spiritual pada siswa Sekolah Dasar ini menggunakan prosedur yang dikembangkan oleh Djaali dan Puji Muljono 
(2008: 60-62) mulai sintesis dari teori-teori yang dikaji kemudian dirumuskan menjadi konstruk variabel sikap spiritual dalam bentuk definisi konseptual yang tercermin dari dimensi afeksi, kognisi, dan konasi serta indikatornya, membuat kisi-kisi instrumen terdiri dari 18 butir afeksi, 20 butir kognisi, dan 32 butir konasi dengan nomor dari I sampai dengan 70, menetapkan besaran atau rentang parameter yang bergerak dari negatif (tidak setuju) ke positif (setuju), validasi teoretik melalui pemeriksaan pakar atau panelis berjumlah 20 orang menggunakan content validaty Aiken dan reliabilitas interrater, validasi empirik untuk analisis daya diskriminasi butir dengan product moment Pearson dan analisis faktor menggunakan SEM dengan second order confirmatory factor analysis dengan kriteria dimensi dianggap memenuhi syarat reliabilitas konstruk, yaitu: 0.80 $\leq$ GFI $<$ I, $0.80 \leq$ AGFI $<1,0.05<R M S E A \leq 0.08$, $R M R<0.05,0.80 \leq N F I<I, 0.80 \leq N N F I<1,0.80 \leq$ $C F|<I, 0.80 \leq I F|<I$, dan $0.80 \leq R F \mid<I$, maka model dianggap sudah memenuhi kriteria dengan factor loading $\geq 0.3$, construct reliability $>0.7$, dan variance extracted $>0.5$.

\section{Hasil Penelitian dan Pembahasan}

Tahap awal penelitian adalah validasi teoritis melalui telaah pakar terhadap draft instrumen yang disusun berupa definisi konseptual dan operasional, kisi-kisi instrumen, dan kuesioner yang akan dinilai butir (itemnya). Hasil telaah pakar pada instrumen sikap spiritual siswa ini adalah beberapa butir mengalami perbaikan dan perubahan kalimat, serta beberapa butir pernyataan direduksi. Untuk dimensi Afeksi, instrumen awal terdiri dari 18 butir, setelah dilakukan telaah pakar, maka menjadi ' 4 butir, jadi butir yang direduksi sebesar $22 \%$. Butir yang direduksi tersebut adalah pada indikator Bersabar menghadapi cobaan dengan tetap taat kepada Tuhan sebanyak 3 butir dan indikator Memiliki rasa kepedulian terhadap sesama manusia dan lingkungan yang didasari kasih sayang Tuhan sebanyak I butir. Untuk dimensi Kognisi, ada beberapa butir pernyataan yang direduksi, yang semula terdiri dari 20 butir kemudian setelah telaah pakar menjadi 14 butir, jadi sebesar 30\% butir yang direduksi. Butir-butir yang direduksi tersebut adalah indikator Memiliki kesadaran bahwa hidup adalah mengabdi kepada Tuhan sebanyak tiga butir dan indikator Memiliki kesadaran diri terhadap kehidupan sebanyak 3 butir.

Untuk dimensi Konasi, ada beberapa butir pernyataan yang direduksi, yang semula terdiri dari 32 butir kemudian setelah telaah pakar butir maka menjadi 26 butir, jadi sebanyak 19\% direduksi. Butir-butir yang direduksi tersebut merupakan butir yang memiliki makna yang sama dengan butir yang lain atau tidak sesuai dengan indikator dan dimensi, juga memiliki taraf kesulitan untuk dipahami oleh siswa Sekolah Dasar. Butir yang tersisa dari hasil reduksi adalah indikator Beribadah, berdzikir, berdo'a, dan memohon ampunan kepada Tuhan agar terjaga hubungan yang baik sebanyak 6 butir, indikator Berkata jujur dan berbuat sesuai dengan hati nurani sebanyak 4 butir, indikator Menciptakan kedamaian dengan cinta dan kasih sayang dari Tuhan sebanyak 4 butir, indikator Menerapkan nilai-nilai ibadah dalam kehidupan sehari-hari sebanyak 9 butir, dan indikator Berusaha dan istiqamah berbuat baik dan membebaskan diri sendiri dan orang lain dari pengaruh negatif hawa nafsu dengan bimbingan ruh llahi sebanyak 3 butir.

Semua butir yang berjumlah 54 butir tersebut valid karena semua butir memiliki nilai positif. Nilai positif pada analisis validitas butir dengan menggunakan validitas Aiken mengidentifikasikan bahwa butir tersebut valid, yang berarti bahwa semua butir tersebut sudah sesuai atau tepat untuk mengukur masing-masing indikator yang menyusun konstruk sikap spiritual. Indikatorindikator yang terdiri dari butir-butir pernyataan tepat atau sesuai untuk mengukur konstruk sikap spiritual siswa. Demikian pula hasil reliabilitas interrater (antar penilai pakar/panelis) menunjukkan nilai yang cukup tinggi, yaitu: mendekati nilai I seperti Tabel I berikut ini: 
Tabel I. Hasil Analisis Reliabilitas Interrater

\begin{tabular}{ccccc}
\hline \multirow{2}{*}{ Nomor Butir } & Dimensi & \multicolumn{2}{c}{ Kriteria Penilaian } & \\
\cline { 3 - 4 } & & $\begin{array}{c}\text { Ketepatan Butir } \\
\text { dengan Indikator }\end{array}$ & $\begin{array}{c}\text { Ketepatan Penggunaan } \\
\text { Bahasa }\end{array}$ & Keterangan \\
\cline { 3 - 4 } & Afeksi & V hitung & V hitung & \\
\hline I. & 0.889 & 0.858 & Reliabel \\
\hline 2. & Kognisi & 0.877 & 0.872 & Reliabel \\
\hline 3. & Konasi & 0.921 & 0.836 & Reliabel \\
\hline
\end{tabular}

Tabel 2.Koefisien Korelasi Butir Total Rendah $\left(r_{x y}\right)$

\begin{tabular}{llcccc}
\hline Dimensi & \multicolumn{1}{c}{ Indikator } & $\begin{array}{c}\text { Butir } \\
\text { Pernyataan }\end{array}$ & $\begin{array}{c}\text { Koefisien } \\
\text { Korelasi Butir } \\
\text { Total }\left(\mathbf{r}_{\mathbf{x y}}\right)\end{array}$ & $\begin{array}{c}\text { Daya } \\
\text { Beda }\end{array}$ \\
\hline \multirow{2}{*}{ Afeksi } & $\begin{array}{l}\text { Merasakan kehadiran Tuhan } \\
\text { dan berserah diri kepadaNya }\end{array}$ & 1 & 0.090 & Rendah \\
\cline { 2 - 5 } Kognisi & $\begin{array}{l}\text { Memiliki kesadaran bahwa } \\
\text { hidup adalah mengabdi kepada } \\
\text { Tuhan }\end{array}$ & 16 & 0.150 & Rendah \\
\hline
\end{tabular}

Berdasarkan Tabel 2. tersebut, ada 3 butir pernyataan yang mempunyai nilai konsistensi rendah, tidak memenuhi nilai minimal koefisien korelasi butir total, yaitu: $r_{x y} \geq 0.159$ dengan $\alpha=$ 0.05. Adapun butir yang memiliki nilai $r_{x y}$ yang tinggi yang diikutsertakan dalam analisis faktor dengan menggunakan Lisrel sebanyak $5 \mathrm{I}$ butir pernyataan, 12 indikator, dan 3 dimensi.

\section{a. Analisis Faktor dengan Metode Structural Equation Modeling (SEM)}

Adapun hasil uji coba model (goodness of fit) konstruk Sikap Spiritual siswa dengan Second
Order CFA sebelum dan sesudah respesifikasi dapat dilihat dari path diagram dan Tabel 3.

Tabel 3 menunjukkan bahwa terdapat I ukuran Goodness of Fit (GOF) yang menunjukkan hasil kecocokan yang kurang baik, sebelum dan sesudah, yaitu: critical number (CN), I ukuran GOF mendekati kurang baik, sebelum dan sesudah, yaitu: PGFI, dan 3 ukuran GOF dari mendekati baik (marginal fit) menjadi baik (good fit), yaitu: chi-square, AIC, dan ECVI, serta 10 ukuran GOF yang menunjukkan kecocokan yang baik (good fit).

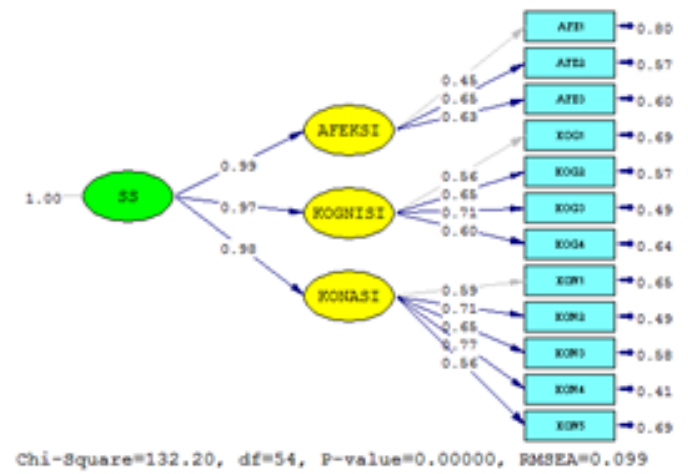

Sebelum

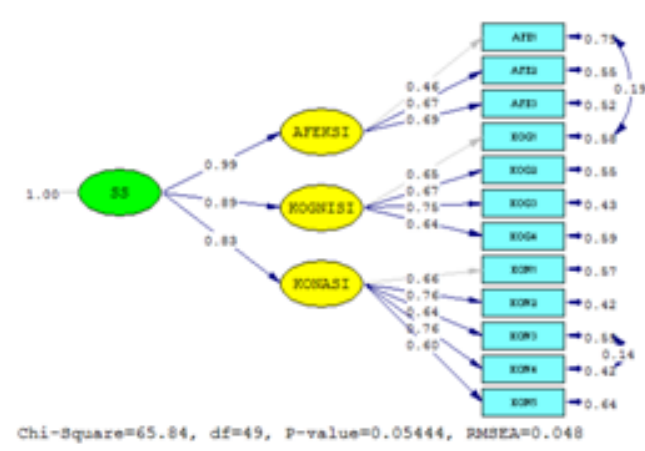

Sesudah

Gambar I. Nilai Loading Factor pada Standardized Solution Sebelum dan Sesudah Respesifikasi Uji Coba I 


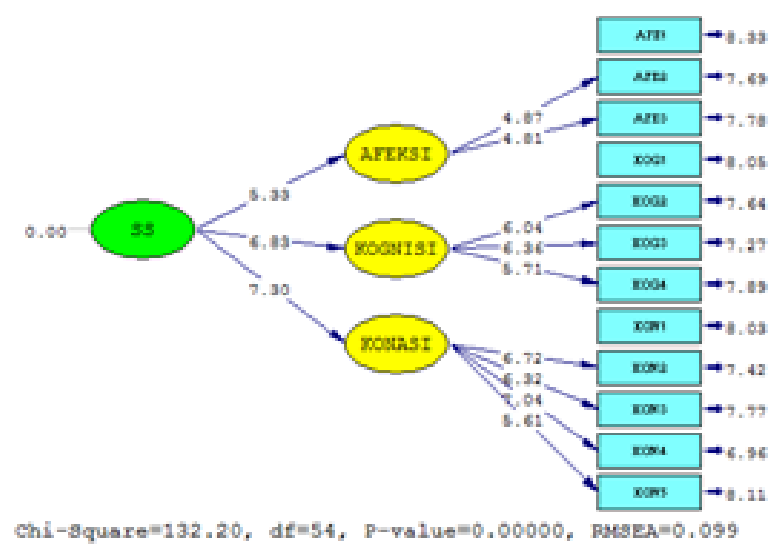

Sebelum

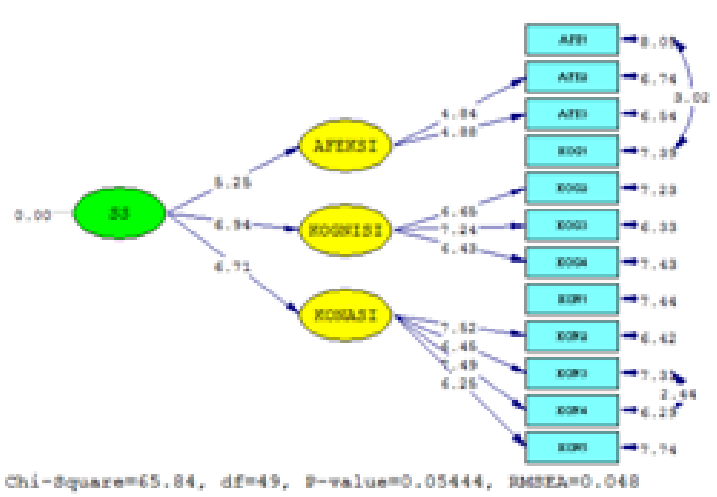

Sesudah

Gambar 2. Nilai $t$ value masing-masing indikator diukur untuk Tiap-tiap Dimensi pada Model Sebelum dan Sesudah Respesifikasi Uji Coba I

Hasil analisis faktor dengan Second Order CFA yang dilakukan terhadap 12 indikator menghasilkan muatan faktor atau loading factor $(\lambda)$ semuanya lebih besar dari 0.3 . Nilai estimasi muatan faktor yang baik menunjukkan bahwa indikator penyusun dapat dengan baik menjelaskan variabel latennya. Selain itu, nilai muatan faktor di bawah 0.3 menunjukkan bahwa indikator ini tidak valid atau memiliki validitas yang rendah. Hal ini senada dengan yang dikatakan oleh Carmines dan Zeller seperti dikutip oleh Sugiyono bahwa konstruk yang baik adalah bila memiliki muatan faktor minimal 0.3 , sehingga apabila $\lambda \geqslant 0.30$, maka dikatakan indikator valid (Sugiyono, 20I2: 330). Dengan demikian uji empiris tahap dua dilakukan dengan 3 dimensi, 12 indikator, dan 5 I butir.

Pada uji signifikansi, nilai $t$ ( $t$ values) seluruh indikator di semua variabel juga memiliki nilai tvalue (t statistik) > 1.96. Ini memberikan makna bahwa semua indikator memberikan informasi yang signifikan terhadap variabelnya. Uji reliabilitas konstruk atau construct reliability (CR) dan Variance Extracted (VE). Hasil perhitungan nilai CR dan VE dapat dilihat pada Tabel 4.

Tabel 3. Hasil Kecocokan Model (Goodness of Fit) Konstruk Sikap Spiritual dengan Second Order CFA Uji Coba I Sebelum dan Sesudah Respesifikasi Model

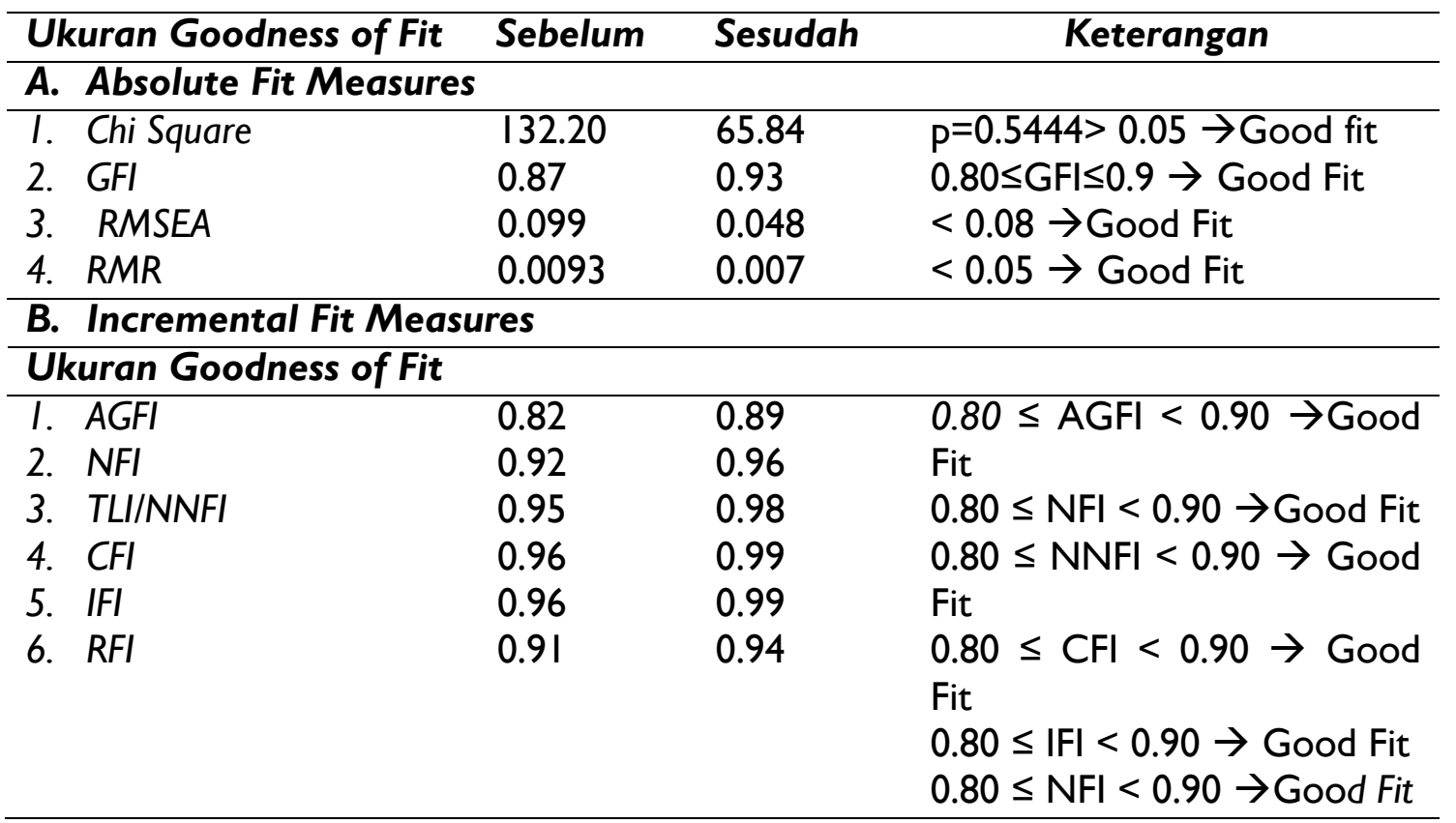




\begin{tabular}{|c|c|c|c|}
\hline Ukuran Goodness of Fit & Sebelum & Sesudah & Keterangan \\
\hline \multicolumn{4}{|c|}{ C. Parsimonious Fit Measures } \\
\hline I. AIC & 180.20 & 123.84 & $\begin{array}{lcr}<156.00 & \text { (Saturated) dan } \\
<1558.51 & \text { (Independence) } & \rightarrow\end{array}$ \\
\hline 2. CAIC & 276.45 & 240.14 & $\begin{array}{l}\text { Good Fit } \\
<468.83 \quad \text { (Saturated) dan }\end{array}$ \\
\hline 3. ECVI & 1.21 & 0.83 & $\begin{array}{l}<1606.63 \text { (Independence) } \rightarrow \\
\text { Good Fit }\end{array}$ \\
\hline 4. PGFI & 0.60 & 0.59 & $\begin{array}{l}<1.05 \text { (Saturated) dan }<10.46 \\
\text { (Independence) } \rightarrow \text { Good Fit } \\
>0.60 \rightarrow \text { Marginal Fit }\end{array}$ \\
\hline \multicolumn{4}{|l|}{ D. Other Measure } \\
\hline I. CN & 103.53 & 167.02 & $\geq 200 \rightarrow$ Kurang Fit \\
\hline
\end{tabular}

Tabel 4. Analisis Reliabilitas Konstruk Model Pengukuran Uji Coba I

\begin{tabular}{cc}
\hline Indikator & Nilai \\
\hline Construct Reliability & 0.905 \\
\hline Varianced Extracted & 0.788 \\
\hline
\end{tabular}

Tabel 4 menunjukkan nilai CR sebesar 0.905 dan nilai VE sebesar 0.788. Dengan demikian dapat dinyatakan bahwa nilai CR dan VE telah memenuhi kriteria, yaitu: nilai $C R>0.7$ dan VE > 0.5. Hal ini berarti model pengukuran untuk mengukur Sikap Spiritual pada siswa SD pada validasi empirik tahap pertama ini dapat dipercaya dan mempunyai konsistensi yang baik. Berikut adalah Tabel Koefisien Korelasi Butir Total Rendah $\left(r_{x y}\right)$ Uji Coba 2:

Tabel 5 Koefisien Korelasi Butir Total Rendah $\left(r_{x y}\right)$ Uji Coba 2

\begin{tabular}{lllll}
\hline Dimensi & \multicolumn{1}{c}{ Indikator } & \multicolumn{1}{c}{$\begin{array}{c}\text { Butir } \\
\text { Pernyataan }\end{array}$} & $\begin{array}{c}\text { Koefisien } \\
\text { Korelasi } \\
\text { Butir Total } \\
\text { (rxy) }\end{array}$ & $\begin{array}{c}\text { Daya } \\
\text { Beda }\end{array}$ \\
\hline AFEKSI & $\begin{array}{l}\text { Memiliki rasa kepedulian terhadap sesama } \\
\text { manusia dan lingkungan yang didasari kasih } \\
\text { sayang Tuhan }\end{array}$ & 4 & 0.124 & Rendah \\
\hline KOGNISI & $\begin{array}{l}\text { Memiliki kesadaran bahwa hidup adalah } \\
\text { mengabdi kepada Tuhan }\end{array}$ & 14 & 0.086 & Rendah \\
\hline KOGNISI & $\begin{array}{l}\text { Memiliki kecenderungan kepada kebaikan } \\
\text { dan kebenaran sebagai kasih sayang dari } \\
\text { Tuhan }\end{array}$ & 17 & 0.029 & Rendah \\
\hline KOGNISI & $\begin{array}{l}\text { Memahami bahwa seseorang memperoleh } \\
\text { balasan dari Tuhan, baik atau buruk, sesuai } \\
\text { dengan perbuatannya }\end{array}$ & 19 & 0.096 & Rendah \\
\hline KOGNISI & $\begin{array}{l}\text { Memiliki kesadaran bahwa hidup adalah } \\
\text { mengabdi kepada Tuhan }\end{array}$ & 21 & 0.027 & Rendah \\
\hline KONASI & $\begin{array}{l}\text { Berusaha dan istiqamah berbuat baik dan } \\
\text { membebaskan diri sendiri dan orang lain } \\
\text { dari pengaruh negatif hawa nafsu dengan } \\
\text { bimbingan ruh llahi }\end{array}$ & 38 & -0.231 & Rendah \\
\hline KONASI & $\begin{array}{l}\text { Menerapkan nilai-nilai ibadah dalam } \\
\text { kehidupan sehari-hari }\end{array}$ & 48 & 0.074 & Rendah \\
\hline
\end{tabular} \begin{tabular}{l} 
KOand \\
\hline
\end{tabular}


Berdasarkan Tabel 5. tersebut, ada 7 butir pernyataan yang memiliki nilai $r_{x y}$ yang rendah, sehingga harus dikeluarkan/dihilangkan/dibuang, dan tidak diikutsertakan pada analisis faktor menggunakan Lisrel karena memiliki daya diskriminasi rendah, yaitu: nilai koefisien korelasi butir totalnya $\leqslant 0.159$ dengan $a=0.05$. Adapun

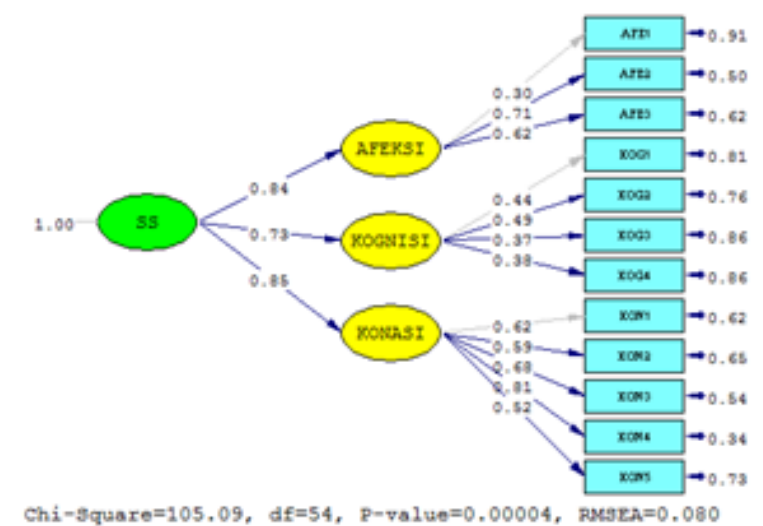

Sebelum butir yang memiliki nilai $r_{x y}$ yang tinggi yang diikutsertakan pada analisis faktor dengan menggunakan Lisrel sebanyak 44 butir.

Hasil uji kecocokan model (goodness of fit) konstruk Sikap Spiritual pada siswa menggunakan Second Order CFA dapat dilihat dari path diagram dan Tabel 6.

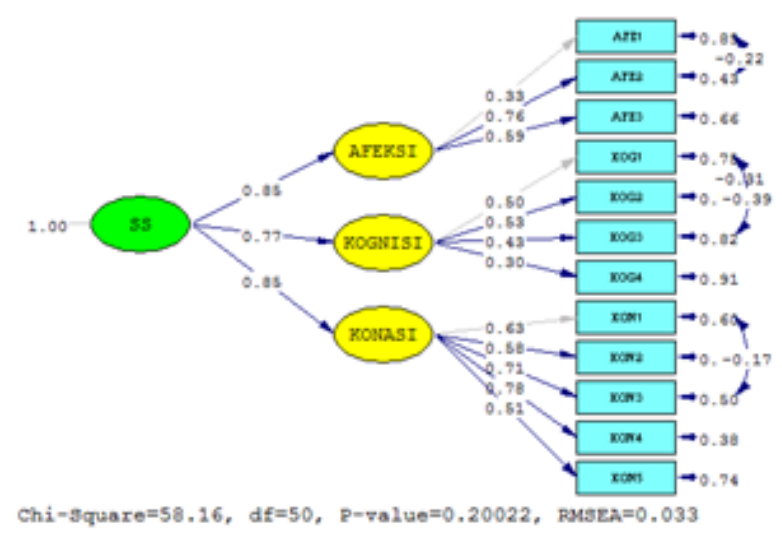

Sesudah

Gambar 3. Nilai Loading Factor pada Standardized Solution Sebelum dan Sesudah RespesifikasiUji Coba 2

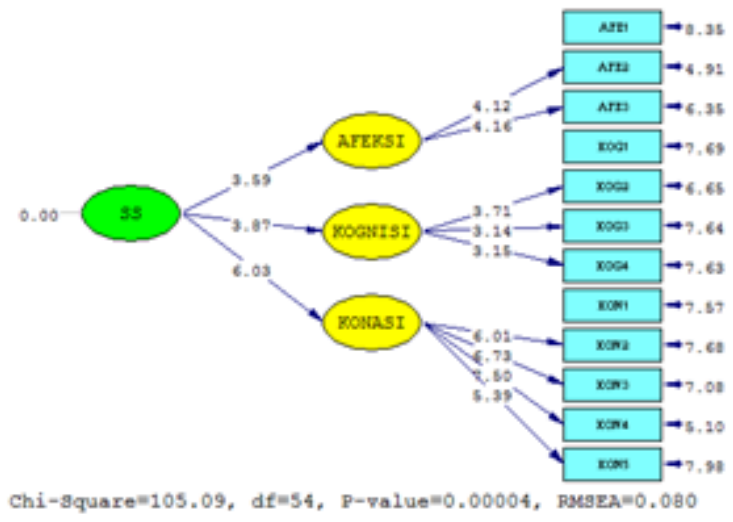

Sebelum

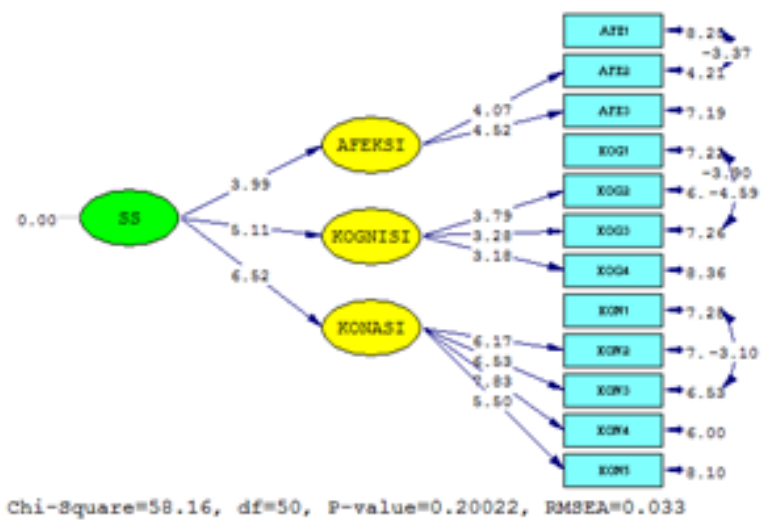

Sesudah

Gambar 4. Nilai t value Masing-masing Indikator Diukur untuk Tiap-tiap Dimensi pada Model Sebelum dan sesudah Respesifikasi Uji Coba 2

Gambar 3. menunjukkan nilai loading factor pada tiap-tiap indikator adalah semua valid dengan $\lambda \geqslant 0.30$. Hal ini dapat dikatakan indikator penyusunan dimensinya masing-masing dapat menjelaskan konstruk latennya dengan baik.
Gambar 4. menunjukkan semua nilai $t$ muatan faktor lebih dari I.96. Hal ini memberikan makna bahwa indikator memberikan informasi signifikan terhadap variabel latennya. 
Tabel 6. Hasil Kecocokan Model (Goodness of Fit) Konstruk Sikap Spiritual dengan Second Order CFA Uji Coba I Sebelum dan Sesudah Respesifikasi Model

\begin{tabular}{|c|c|c|c|}
\hline Ukuran Goodness of Fit & Sebelum & Sesudah & Keterangan \\
\hline \multicolumn{4}{|l|}{ A. Absolute Fit Measures } \\
\hline I. Chi Square & 105.09 & 58.16 & $p=0.20022>0.05 \rightarrow$ Good Fit \\
\hline 2. GFI & 0.89 & 0.94 & $0.80 \leq$ GFI $\leq 0.9 \rightarrow$ Good Fit \\
\hline 3. RMSEA & 0.080 & 0.033 & $<0.08 \rightarrow$ Good Fit \\
\hline 4. $R M R$ & 0.015 & 0.012 & $<0.05 \rightarrow$ Good Fit \\
\hline \multicolumn{4}{|l|}{ B. Incremental Fit Measures } \\
\hline Ukuran Goodness of Fit & & & \\
\hline I. AGFI & 0.84 & 0.90 & $0.80 \leq A G F I<0.90 \rightarrow$ Good Fit \\
\hline 2. NFI & 0.83 & 0.91 & $0.80 \leq N F I<0.90 \rightarrow$ Good Fit \\
\hline 3. TLI/NNFI & 0.88 & 0.98 & $0.80 \leq N N F I<0.90 \rightarrow$ Good Fit \\
\hline 4. CFI & 0.90 & 0.98 & $0.80 \leq C F I<0.90 \rightarrow$ Good Fit \\
\hline 5. IFI & 0.90 & 0.98 & $0.80 \leq|F|<0.90 \rightarrow$ Good Fit \\
\hline 6. RFI & 0.80 & 0.88 & $0.80 \leq N F I<0.90 \rightarrow$ Good Fit \\
\hline \multicolumn{4}{|l|}{ C. Parsimonious Fit Measures } \\
\hline I. AIC & 153.09 & 114.16 & $\begin{array}{l}<156.00 \text { (Saturated) dan }<7 / 3.79 \\
\text { (Independence) } \rightarrow \text { Good Fit }\end{array}$ \\
\hline 2. CAIC & 249.35 & 226.45 & $\begin{array}{l}<468.83 \text { (Saturated) dan }<761.92 \\
\text { (Independence) } \rightarrow \text { Good Fit }\end{array}$ \\
\hline 3. ECVI & 1.03 & 0.77 & $\begin{array}{l}<1.05 \quad \text { (Saturated) dan }<4.79 \\
\text { (Independence) } \rightarrow \text { Good Fit }\end{array}$ \\
\hline 4. PGFI & 0.62 & 0.60 & $>0.60 \rightarrow$ Good Fit \\
\hline D. Other Measure & & & \\
\hline I. $\mathrm{CN}$ & 106.23 & 189.35 & $\geq 200 \rightarrow$ Kurang Fit \\
\hline
\end{tabular}

Tabel 6. menunjukkan I ukuran GOF, yaitu: critical number (CN) menghasilkan kecocokan yang kurang baik, I ukuran GOF, yaitu: PGFI, menghasilkan kecocokan yang mendekati baik (marginal fit). Adapun ukuran GOF lainnya, yaitu: GFI, RMSEA, RMR, AGFI, NFI, NNFI, CFI, IFI, RFI, AIC, CAIC, dan ECVI menghasilkan kecocokan yang baik (good fit). Dengan demikian, hasil respesifikasi model ini telah memenuhi hampir keseluruhan kriteria nilai cut off yang dipersyaratkan untuk model fit, sehingga dikatakan model fit (tepat). Adapun kesimpulan hasil analisis faktor dapat dilihat pada Tabel 7 berikut ini:

Tabel 7. Analisis Reliabilitas Konstruk Model Pengukuran Uji Coba 2

\begin{tabular}{cc}
\hline Indikator & Nilai \\
\hline Construct Reliability & 0.846 \\
\hline Varianced Extracted & 0.599 \\
\hline
\end{tabular}

Tabel 7. menunjukkan CR sebesar $0.846>0.7$ dan nilai VE sebesar $0.599>0.5$. Hal ini berarti bahwa model pengukuran untuk mengukur Sikap Spiritual pada siswa Sekolah Dasar ini dapat dipercaya dan mempunyai konsistensi yang baik. Jadi, model pengukuran untuk mengukur Sikap Spiritual pada siswa Sekolah Dasar memiliki reliabilitas yang baik dan valid.

\section{Kesimpulan}

Berdasarkan hasil uji empiris yang dilakukan sebanyak dua kali uji coba, maka dapat disimpulkan bahwa instrumen Sikap Spiritual pada siswa Sekolah Dasar ini ada 3 dimensi dan 12 indikator membangun konstruk teori Sikap Spiritual pada siswa Sekolah Dasar, yaitu: (I) Dimensi Afeksi meliputi indikator: (a) Merasakan kehadiran Tuhan dan berserah diri kepadaNya, (b) Bersabar menghadapi cobaan dengan tetap taat kepada Tuhan, dan (c) Memiliki rasa kepedulian terhadap sesama manusia dan lingkungan yang didasari kasih sayang Tuhan, (2) Dimensi Kognisi meliputi indikator: (a) Memiliki kesadaran bahwa hidup adalah mengabdi kepada 
Tuhan, (b) Memiliki kesadaran diri terhadap kehidupan, (c) Memiliki kecenderungan kepada kebaikan dan kebenaran sebagai kasih sayang dari Tuhan, dan (d) Memahami bahwa seseorang memperoleh balasan dari Tuhan, baik atau buruk, sesuai dengan perbuatannya, dan (3) Dimensi Konasi meliputi indikator: (a) Beribadah, berdzikir, berdo'a, dan memohon ampunan kepada Tuhan agar terjaga hubungan yang baik, (b) Berkata jujur dan berbuat sesuai dengan hati nurani, (c) Menciptakan kedamaian dengan cinta dan kasih sayang dari Tuhan, (d) Menerapkan nilai-nilai ibadah dalam kehidupan sehari-hari, dan (e) Berusaha dan istiqamah berbuat baik dan membebaskan diri sendiri dan orang lain dari pengaruh negatif hawa nafsu dengan bimbingan ruh Ilahi.

Uji kecocokan model menggunakan SEM menghasilkan model akhir yang sudah tepat untuk mengukur Sikap Spiritual pada siswa SD berdasarkan nilai GOF yang memenuhi kriteria nilai cut-off yang dipersyaratkan, meliputi: chi square, GOF, RMSEA, RMR, AGFI, NFI, NNFI, CFI, IFI, RFI, AIC, CAIC, ECVI, PGFI, dan CN. Instrumen ini juga sudah reliabel dengan nilai Construct Reliability (CR) dan Variance Extracted (VE) di atas nilai cut-off, yaitu: $C R=0.846>0.7$ dan VE $=0.599>0.5$. Instrumen Sikap Spiritual pada siswa SD sudah valid dan reliabel. Perbaikan yang perlu dilakukan adalah dengan menambah butir pernyataan dalam dimensi Sikap Spiritual, yaitu: afeksi, kognisi, dan konasi, perlu dibuat lebih dari satu versi dengan validitas dan reliabilitas yang relatif sama dengan sebelumnya sehingga dapat menjadi pembanding untuk menganalisis dan memetakan Sikap Spiritual peserta didik lebih akurat, dan terakhir, pengembangan instrumen ini perlu perbaikan bahasa yang lebih mudah dipahami oleh siswa SD sehingga tujuan mengukur Sikap Spiritual dapat tercapai dengan seminimal mungkin terjadi hambatan dalam memahami maksud butir pernyataan.

\section{Daftar Pustaka}

Azwar, Saifuddin (1988). Sikap Manusia, Teori dan Pengukurannya. Yogyakarta: Penerbit Liberty.

Bridges, Lisa J., Moore Kristin A. (2002). Religion and Spirituality in Childhood and Adolescence. Bethesda: Child Trends.

Djaali dan Muljono, Pudji (2008). Pengukuran dalam Bidang Pendidikan. Jakarta: PT. Grasindo.

Eagly, Alice H. and Chaiken, Shelly. (1993). The Psychology of Attitudes. Orlando: Harcourt Brace Jovanovich, Inc.

Fishbein, Martin and Ajzen, Icek Belief. (1975). Attitude, Intention and Behavior, An Introduction to Theory and Research. MA: Addison-Wesley Publishing Company, Inc.

Hawari, Dadang. (1996).Al Qur'an Ilmu Kedokteran Jiwa dan Kesehatan Jiwa. Yogyakarta: Penerbit PT. Dana Bhakti Prima Yasa.

Safaria, Triantoro. (2007). Spiritual Intelligence Metode Pengembangan Spiritual Anak. Yogyakarta: Graha IImu

Sugiyono. (2012). Statistika untuk Penelitian. Bandung: Alfabeta.

Thiagarajan, S. Semmel, D. S. dan Semmel, M. S. (1974). Instructional Development for Training Teachers of Exceptional Children: A Source of Book. Indiana: Indiana Universtity. 